\title{
A VEGETAÇĀO DE RESTINGA NO MUNICÍPIO DE MARICÁ - RJ (1)
}

\author{
Janie Garcia da Silva (2) \\ Arline Souza de Oliveira (3)
}

\begin{abstract}
RESUMO - Este levantamento da vegetação de restinga no Município de Maricá, executado no período de 1985 a 1988, abrange 379 espécies, em continuação a estudos anteriores em Barra de Maricá, Rio de Janeiro, Brasil. Os estudos e observações realizadas, comparam as localidades de Barra de Maricá e Itaipuaçu e mostram a distribuiçâo das espécies no ambiente em função de características topográficas e outras particularidades, permitindo relacionar e descrever 10 comunidades dentro do ecossistema.
\end{abstract}

Palavras-chave: restinga, Maricá, Rio de Janeiro, vegetação, flora.

\begin{abstract}
This survey of the "restinga" vegetation in the Maricá Municipal District, performed from 1985 to 1988 , perceive 379 species in continuation to early studies in Barra de Maricá, Rio de Janeiro, Brazil. This paper wish to compare the localities of Barra de Maricá and Itaipuaçu, showing the distribution of species in relation to topography and others environment factors. Ten comunities are described in the ecosystem.
\end{abstract}

Key words: restinga, Maricá, Rio de Janeiro, vegetation, flora.

\section{Introduçäo}

O termo "restinga" aqui adotado, refere-se à vegetação ocorrente sobre depósitos arenosos costeiros característicos do litoral brasileiro (SUGUIO \& TESSLER, 1984).

A costa fluminense é constituída por depósitos sedimentares provenientes de regressões e transgressöes marinhas ocorridas no Quaternário (PERRIN,

(1) Programa Linhas de Ação em Botânica, Ecossistema Restinga (CNPq).

(2) Depto. de Biol. Geral-IB-UFF. Outeiro de S. Joăo Baptista s/nº. Niterói, Centro, RJ. 24021.

(3) Depto. de Botânica-Museu Nacional-UFRJ, Quinta da Boa Vista, s/n. São Cristovão, Rio de Janeiro. 20942. 
1984). Esses movimentos levaram a formação de cordões arenosos onde ficaram aprisionados sistemas de dunas e alagados (MUEHE, 1984; FLEXOR, 1984).

No litoral do Município de Maricá, as feições topográficas são bastante heterogêneas. Entre Ponta Negra e Ponta do Fundão, os processos sedimentares originaram um cordão arenoso simples; entre Barra de Maricá e Itaipuaçu há um duplo cordão (PERRIN, 1984). Em Itaipuaçu, encontramos ainda um terceiro cordão "formado pelo alinhamento sobre um terraço arenoso que corresponderia a uma antiga alta praia, formada no decorrer da pregradação costeira" (FLEXOR, 1984).

As pesquisas de KAPLAN \& colaboradores (1983) a partir de 1981 sobre ecologia química dessa vegetação, em excursões mensais, levaram à coleta de material botânico e de observações que resultaram em levantamento e estudos (SILVA \& SOMNER, 1983, 1984, 1984a), com base em Barra de Maricá. A partir de 1985, os estudos estenderam-se ao litoral de Itaipuaçu.

Nesse trabalho, continua-se o levantamento, enfocando o trecho de Maricá-Itaipuaçu. Apresenta-se uma análise da região como um todo, comparando-se as duas localidades, além de se reconhecer e delimitar as comunidades vegetais que compõe o ecossistema estudado.

\section{Material e Métodos}

Foram realizadas excursões quinzenais à região para coletas, observação e documentação fotográfica.

As espécies reconhecidas em campo, foram apenas assiraladas. $\mathrm{O}$ material a ser identificado, foi preparado segundo as técnicas usuais.

$\mathrm{Na}$ determinação das espécies, recorreu-se às obras de MARTIUS (1840-1906), a diversos trabalhos pertinentes e alguns especialistas. Recorreuse ainda à comparação com exsicatas depositadas no Herbário Alberto Castelhanos (GUA), Herbarium Bradeanum (HB), do Jardim Botânico do Rio de Janeiro (RB) e do Museu Nacional $\left(R_{*}\right)$. Este último, tornou-se depositário das coletas realizadas a fim de se manter registros da flora regional.

As espécies foram relacionadas em ordem alfabética de família com seus respectivos autores e indicações de ocorrência na área (Tabela 1). A nomenclatura vulgar foi extraída em sua maioria de fontes bibliográficas (CORREA, 1976; ESTEVES, 1980; SAMPAIO, 1946). As observações baseiam-se no trabalho de campo, durante as coletas e, por vezes, na bibliografia (ANDRADE \& al., 1982; ARAÚJO \& HENRIQUES, 1984; BERG, 1972; CARAUTA \& COIMBRA, 1982; ORMOND, 1960; PRANCE, 1972; SILVA \& SOMNER, 1983, 1984; SMITH, 1955).

Os perfis de vegetação (figs. 1-4), traçados com mapas e cartas topográficas (BRASIL-FUNDREM, 1979; BRASIL-DSG, 1982), mostram a distribuição das comunidades vegetais descritas a partir das observações de campo sobre a região como um todo. A análise dos resultados obtidos permitiu uma comparação entre a vegetação das localidades de Itaipuaçu e Barra de Maricá. 


\section{Resultados}

$\mathrm{Na}$ formação típica dos duplos cordões arenosos, o interno (chamado 2 ㅇ cordão nesse trabalho), "é mais largo, por vezes mais baixo, de formas suaves e encontra-se colonizado por uma vegetação lenhosa, esclerófila, distribuída em maciços irregulares", com elementos arbóreos mais desenvolvidos. O cordão externo (tido por $1^{\circ}$ cordão), possui formato irregular e, sofre mais intensamente a ação dos ventos, sendo recoberto em parte por "vegetação predominantemente arbustiva, baixa" (PERRIN, 1974).

O 3 o cordão, encontrado em Itaipuaçu, possui topografia acentuada em certos trechos e cobertura arbórea bem desenvolvida. Entre os elementos do $2^{\circ}$ e $3^{\text {o }}$ cordões, ocorrem também alguns representantes de mata provenientes de montanhas adjacentes à Serra do Mar, e que colonizaram sucessivamente aquela região. No entanto, a composição desses elementos nesses cordões é bem diversificada. Segundo RIZZINI (1979), a flora de restinga teve origem a partir da Mata Atlântica e, para ele, "um melhor conhecimento da distribuição das espécies tidas como endêmicas, pode revelar que algumas também são de origem florestal".

A faixa entre o $1^{\circ}$ e o $2^{\circ}$ cordão, de dimensões variáveis, é pouco acidentada, pantanosa, ou com bolsões de umidade em alguns trechos devido ao lençol freático superficial. É frequente a comunidade higrófila de brejo herbáceo, e em locais de solo mais seco, encontra-se a vegetação de restinga aberta.

Após o 2\% cordão, ocorrem as comunidades de restinga aberta, as de brejo e de alagados resultantes da colmatação de antigas lagunas e áreas de inundação periódica por elevação do lençol freático e nível dos cursos d'água, que permanecem úmidas, mesmo em períodos de estiagem. Em alguns trechos há remanescentes de mata.

Nos pontos que sofreram ação antrópica, verifica-se a ocorrência de espécies invasoras e subespontâneas. Das espécies nativas, os cactos, o guriri e as bromélias são os primeiros a ocupar esses locais, conferindo-lhes um aspecto agreste. Isso é mais comum em Itaipuaçu, onde o processo de ocupação do solo é mais acelerado. Nesse processo de recomposição da flora, as bromélias, principalmente Neoregelia cruenta, desempenham importante função preparando o solo para repovoamento (HAY \& al., 1981; HAY \& LACERDA, 1980; HAY \& TAN, 1981).

\section{Descrição dos perfis}

No estudo da região, foram traçados perfis de vegetação no sentido marinterior (figs. 1-4).

Perfil 1

A zonação observada nesse perfil com cerca de $500 \mathrm{~m}$, em Barra de Maricá é interrompida por uma estrada nas proximidades da Lagoa de Maricá. A 
vegetação, de modo geral, bastante preservada nesse ponto foi motivo para a sua escolha como representativo nas comparações com os demais. São encontradas as comunidades: halófita, psamófita-reptante, de pós-praia, $1^{\circ}$ e $2^{\circ}$ cordão.

A comunidade halófita, em certas épocas do ano, sofre mais intensamente a ação das marés (sizígias) e tem seu espaço físico reduzido ou restrito ao das psamófitas, de onde se recompõe.

A posição da comunidade pós-praia, por vezes modifica-se pela ação dos

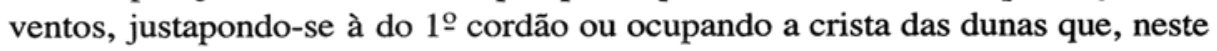
perfil, tem certa mobilidade.

A vegetação do 1\% cordão, em geral abrigada pelas dunas, é compacta em alguns trechos formados por um emaranhado de difícil penetração.

Entre o duplo cordão, predomina a "restinga aberta". $\mathrm{O}$ "brejo herbáceo" limita-se a bolsões de umidade, variáveis de 2 a $10 \mathrm{~m}$ de diâmetro, mantendo sua fase mais vigorosa em períodos chuvosos, quando o lençol freático se encontra mais elevado. Durante o ano, pode ocorrer uma sucessão de espécies de curta duração, inclusive com a participação de líquens (em especial Cladonia). Periodicamente, o solo fica quase nú, com vestígios de uma vegetação que se renova por meio de estolōes e rizomas.

No 2 e cordão, predomina a vegetação arbórea, com altura média de 4 a $8 \mathrm{~m}$, sob a qual se desenvolvem numerosas epífitas.

\section{Perfil 2}

Este perfil, próximo ao Posto de Rastreamento da Aeronáutica em Barra de Maricá, abrange $1 \mathrm{~km}$ de extensão, possuindo as mesmas comunidades mencionadas no anterior e cobertura vegetal relativamente preservada, principalmente no $1^{\circ}$ e $2 \%$ cordões.

As comunidades halótica e psamófita reptante se interpenetram, com elementos da primeira ocorrendo na segunda. A de pós-praia, mais desenvolvida, vem logo a seguir.

A vegetação do 1 \% cordão é predominantemente arbustiva, enquanto que a do 2 é arbóreo-arbustiva.

O brejo herbáceo, com cerca de $150 \mathrm{~m}$ de extensão, é característico, bem desenvolvido e permanente mesmo em períodos de estiagem, quando então diminui suas dimensões. De acordo com o nível de inundação, este ambiente apresenta variações sazonais marcantes (CARMO \& LACERDA, 1984).

\section{Perfil 3}

Neste caso, foi escolhido um trecho em Itaipuaçu, com cerca de $2 \mathrm{~km}$ na direção da antiga Lagoa Brava. Percebe-se todas as comunidades dos perfis anteriores, alteradas em alguns locais pela ação antrópica.

A área entre o $1^{\circ}$ e $2^{\circ}$ cordão é cortada por um canal paralelo à costa, junto do qual ocorre principalmente o brejo herbário, além de elementos dos ala- 
gados (Typha, Dalbergia, Caperonia), Essas comunidades são bastante limitadas em extensão, em espécies e número de indivíduos que se reduzem ou desaparecem nos períodos de estiagem em alguns pontos.

A "restinga aberta" acha-se nos declives do $2^{\circ}$ cordão arenoso, sendo mais exuberante na face posterior. Uma das espécies comuns é Leucothoe revoluta, encontrada também na vegetação do $2 \%$ cordão.

Os alagados ocupam quase a metade do perfil após o 20 cordão, possuindo abundância de estrato herbáceo e de arbustos formando moitas densas. Na transição dos alagados e áreas inundáveis para locais secos, são comuns Gaylussacia brasiliense e Humiria balsamifera.

Perfil 4

O trecho enfocado abrange $1,6 \mathrm{~km}$ em Itaipuaçu, nas proximidades do Morro da Peça até a curva do rio Itocaia onde se percebe um 3 cordão arenoso. À excessão deste cordão, a vegetação está bastante alterada. Algumas comunidades tem distribuição diversa da observada nos perfis anteriores: a psamófila reptante se estende após o relevo do 1 을 cordão onde falta a vegetação correspondente, assim como a de pós-praia.

Segundo Muehe (1984), na área que corresponde ao 1ำ cordão, “o desenvolvimento das dunas é insipiente devido à ausênci: de grãos com imensões adequadas ao transporte eóleo". Este fato, aliado à ativa ação antrópica, provavelmente contribuiram para a descaracterização das comunidades, quando se compara este perfil com os demais.

O brejo herbáceo é semelhante ao descrito no 3ำ perfil. As comunidades de alagado e de áreas inundáveis, são encontradas normalmente entre o $2^{\circ}$ e o 3 - cordões. No último ambiente ocorrem certas espécies diferentes das existentes em outros pontos da mesma comunidade, como Oxypetalum alpinum var. alpinum, coletado somente nas baixadas inundáveis próximas ao rio Itocaia.

\section{Descrição das comunidades}

As espécies se distribuem dinamicamente sem obedecer uma demarcação, porém é possível reconhecer na região formações características que chamamos comunidade.

Verificou-se que certas espécies predominam ou são exclusivas em determinadas comunidades (Alternanthera maritima, Blutaparon portulacoides, $\mathrm{Hy}$ banthus calceolaria, Sophora tomentosa, Pereskia aculeata, Mimosa ceratonia, Byrsonima sericea além de Pilosocereus arrabidae, Cereus fernambucensis, das bromeliáceas). Outras ainda, apresentam ampla dispersão tanto nas restingas do Rio de Janeiro como fora desse ecossistema (Eugenia uniflora, Schinus terebenthifolius, Alchornea triplinervea, Estherazia splendida). Há espécies que, curiosamente são encontradas também acima de $1.000 \mathrm{~m}$ de altitude como é o caso de Achyrocline satureoides e Oxypetalum alpinum var. alpinum. 
As comunidades são descritas a seguir:

A: Halófita - comunidade herbácea típica, sujeita à ação das marés, sendo comuns: Ipomoea pes-caprae, Blutaparon portulacoides, Alternanthera maritima.

B: Psamófita reptante - cobertura herbácea com elementos característicos. Destacam-se: Ipomoea littoralis, Sporobolus virginicus, Mariscus pedunculatus, Stenotaphrum secundatum, Mollugo verticillata.

C: Pós-praia - os elementos herbáceos, em geral são aqueles da comunidade anterior, além de: Hybanthus calceolaria, Stachytarpheta sp., Acycarpha spathulata. Na vegetação de porte arbustivo, predominam Schinus terebenthifolius, Eugenia uniflora, Cereus fernambucensis e Bumelia obtusifolia. A maioria desses componentes são encontrados mais para o interior e com porte arbóreo. D: 1\% cordão arenoso - faixa com numerosas espécies arbóreo - arbustivas, em que predominam: Cereus fernambucensis, Neoregelia cruenta, Norantea brasiliensis, Allagoptera arenaria, Vriesea neoglutinosa, Bromelia, antiacantha, Clusia fluminense, Clusia lanceolata, Selenicereus setaceus, Heisteria perianthomega. Ocorrem ainda: Mimosa ceratonia e Pereskia aculeata, raramente encontrada fora desta faixa. A vegetação arbustiva pode estar substituída por um estrato herbáceo ou subarbustivo (perfil 4).

E: Brejo herbáceo - vegetação herbácea característica, representada por várias gramíneas e ciperáceas, além de: Xyris jupicai, Nymphoides indica, Ludwigia octovalvis, Paepalanthus spp., Pterolepis glomerata. O brejo herbáceo é marcante no perfil 2.

F: 2\% cordão arenoso - comunidade arbóreo-arbustiva. Quando preservada, ela é densa e fechada, mas aberta em determinados locais. São mais comuns: Leucothoes revoluta, Aspidosperma pyricollum, Anacardium occidentale, Byrsonima sericea, Anabaenella tamnoides, Tapirira guianensis, Cupania emarginata, Swartzia apetala, entre outras.

G: Restinga aberta - formada por muitas esparsas, com um indivíduo dominante (geralmente Byrsonima sericea, Rapanea parvifolia, Clusia fluminense, Clusia lanceolata, Tapirira guianensis, ou uma das espécies de Myrtaceae), com altura média de 1,5 a $2 \mathrm{~m}$ e numerosas epífitas, lianas e outras umbrófilas. Em locais mais úmidos, são comuns Gaylussacia brasiliense e Humiria balsamifera, típicas de áreas inundáveis.

$\mathrm{H}$ : Áreas inundáveis - comunidade higrófila que se mantém úmida mesmo em períodos de seca. O estrato herbáceo é dominante sobre o arbóreo-arbustivo. São mais comuns: Alchornea triplinervea var. janeirense, Ilex amara, Marcetia taxifolia e diversas espécies de gramineas. Esta comunidade é mais expressiva no perfil 3.

I: Alagados - vegetação higrófila das áreas permanentemente inundadas. A cobertura vegetal é arbustiva, com estrato herbáceo composto de várias gramíneas e ciperáceas. É facilmente observavel nos perfis 3 e 4 .

J: 3 cordão - zona constituída por antigos cordões de restinga e cuja cobertura é predominantemente arbóreo-arbustiva. Possui elementos de transição da Mata Atlântica e pode ser nitidamente reconhecida no $4^{\circ}$ perfil. 
No levantamento realizado na região (tabela 1), evitou-se as espécies ruderais e subespontâneas, embora algumas sejam mencionadas devido à sua ocorrência em áreas pouco alteradas. O levantamento porém não deve ser considerado completo, já que em alguns pontos as coletas não foram exaustivas.

\section{Conclusōes}

Foi possível observar que a flora da restinga no Município de Maricá é bem diversificada. As 84 famílias encontradas, abrangem 379 espécies pertencentes a 268 gêneros.

As famílias mais numerosas são: Leguminosae, Compositae, Euphorbiaceae, Orchidaceae, Bromeliaceae, Rubiaceae, Myrtaceae, Cactaceae, com respectivamente $29,22,21,16,15,15,14$ e 13 espécies. Representantes de algumas famílias como Anacardiaceae, Cactaceae, Palmae, Malpighiaceae, Clusiaceae destacam-se por um elevado número de indivíduos.

Qualitativamente, algumas espécies são expressivas do ponto de vista biológico, seja como alimento para a fauna ou dentro da comunidade. Entre as halófitas e psamófitas, são típicas: Alternanthera maritima, Blutaparon portulacoides, Sporobulus virginicus, Mariscus pedunculatus, Ipomoea pes-caprae, Ipomoea littoralis. Destacam-se no trecho pós-praia: Sophora tomentosa, Eugenia uniflora, Schinus terebenthifolius e Cereus fernambucensis que aí sempre ocorrem com porte bastante reduzido, sendo que a primeira é mais raramente observada para o interior. Além de Eugenia uniflora, Schinus terebenthifolius, Clusia lanceolata e Clusia fluminense e algumas outras que aí tem porte predominantemente arbustivo, destacam-se ainda no 1 o cordão Cereus fernambucensis, Allogoptera arenaria e Neoregelia cruenta. Esta última, encontrada em quantidade por toda restinga é provavelmente uma das espécies de maior importância dentro do ecossistema.

No brejo herbáceo são mais expressivas as famílias Cyperaceae, Gramineae, Xyridaceae, com várias espécies típicas dessa comunidade. Na vegetação de restinga aberta destacam-se as bromelias, particularmente Neoregelia cruenta e Vriesea neoglutinosa contornando as orlas das moitas e Tillandsia stricta como epífita. No 2 e e 3 o cordões, há numerosas espécies típicas, a maioria de porte arbóreo. Destacam-se como importante, os cambuís, as pitangas, o murici, a aroeira e o guriri que servem de alimento para a fauna local, entre outras espécies.

Em função da análise dos perfis, verifica-se que a flora é bastante heterogênea havendo, inclusive, uma diversidade na composição florística de Barra de Maricá e Itaipuaçu. Foi obervado ainda que:

- algumas espécies tem preferências por determinado tipo de ambiente dentro do referido ecossistema;

- confirma-se uma distribuição das espécies no sentido mar-interior, assinalada em estudo anterior (SILVA \& SOMNER, 1983);

- de acordo com peculiaridades topográficas, edáficas e outras particularidades, há também uma dispersão característica de espécies no sentido paralelo 
ao mar, tendo mesmo algumas uma localização restrita quando se compara as duas localidades.

\section{Agradecimentos}

A todos que contribuíram na identificação de algumas espécies, em particular os especialistas.

\section{Referências Bibliográficas}

ANDRADE, A.G.; ANDRADE, J.C. \& CARAUTA, J.P.P. 1982. Espécies raras ou ameaçadas de extinção. Flora II. Série Técnica da FEEMA, RJ, 18/82: 1-9.

ARAUJO, D.S.D. de \& HEivRIQUES, P.B.R. 1984. Análise florística das restingas do Estado do Rio de Janeiro. In: Anais do Simpósio sobre Restingas Brasileiras, 1: 159-193 ill. EDUFF. Niterói, RJ.

BERG, C.C. 1972. Olmedieae-Brosimeae. Monografia. Flora Neotr., NY. 7: 161-218.

BRASIL. Diretoria do Serviço Geográfico do Exército. 1982. Carta Topográfica do Município de Maricá, RJ. 3 reimpressão (reconstituição de 1964). Escala 1:50.000. DSG. RJ.

— . Fundação para o Desenvolvimento da Região Metropolitana, 1979. Plano Diretor Urbano de Maricá. FUNDREM. RJ. 176p. ill.

CARAUTA, J.P.P. \& COIMBRA, Fº, A.F. 1982. Espécies raras ou ameaçadas de extinção. Flora II. Série Técnica da FEEMA, RJ, 18/82: 27-31.

CARMO, M.A.M. do \& LACERDA, L.D. de. 1984. Limnologia de um brejo de dunas em Maricá, RJ. In: Anais do Simpósio sonre Restingas Brasileiras. 1: 455-460. EDUFF, Niterói, RJ.

CORRÊA, M.P. 1976. Dicionário das plantas úteis do Brasil e das exóticas cultivadas. RJ, Min. da Agric. IBDF. 6v.

ESTEVES, G.L. Contribuição ao conhecimento da vegetação de restinga de Maceió. Bol. Téc. Coord. Meio Amb. Maceió, AL.. 1: 1-42.

FLEXOR, L.M.; SUGUIO, K. \& DOMINGUES, J.L.M. 1984. Gênese dos cordões litorâneos da parte central da costa brasileira. In: Anais do Simpósio sobre Restingas Brasileiras, 1: 35-45 ill. EDUFF. Niterói, RJ.

HAY, J.D.; HENRIQUES, R.B.P. \& LIMA, D.M. 1981. Quantitative comparaisons of dune and foredune vegetation in restinga ecossystems in the state of Rio de Janeiro. Rev. Brasil. Biol., RJ. 41(3): 655-662.

— . \& LACERDA, L.D. de. 1980. Alteraçōes nas características do solo após a fixação de Neoregelia cruenta (R. Grah.) L. Smith. (Bromeliaceae) em ecossistemas de restinga. Cien. Cult., RJ. 32(7): 863-867.

HAY, J.D. \& LACERDA, L.D. de. 1984. Ciclagem de nutrientes no ecossistema de restinga. In: Anais do Simpósio sobre Restingas brasileiras, 1: 461-477. EDUFF. Niterói, RJ.

— $;-$ \& TAN, L.A. 1981. Soil increase in a tropical sand dune ecosystem due to a terrestrial bromelied. Ecology, 62(5): 1392-1395.

HENRIQUES, R.P.B.; MEIRELLES, M.L. \& HAY, J.D. 1984. Ordenação e distribuição de espécies das comunidades vegetais na praia da restinga de Barra de Maricá, Rio de Janeiro. Revta. Brasil. Bot., 7: 27-36.

KAPLAN, M.A.C.; FIGUEIREDO, M.R. de \& GOTTLIEB, O.R. 1983. Variations in 
cyanogenesis in plants with seasons and insect pressure. Biochemical Systematics and Ecology, 11: 367-370.

LOURO, R.P. \& SANTIAGO, L.J.M. 1984. A região de Barra de Maricá, RJ e a importância de sua preservação. Atas da Soc. Bot. Bras., RJ. 2(15): 109-120.

MARTIUS, C.F. von. 1840/1906. Flora Brasiliensis. Monacchi. Monacchi et Lipsiae. $42 \mathrm{v}$.

MUEHE, D. 1984. Evidências de recuo dos cordões litorâneos em direção ao continente no litoral do Rio de Janeiro. In: Anais do Simpósio sobre Restingas Brasileiras, 1: 75-80 ill. EDUFF. Niterói, RJ.

ORMOND, W.T. 1960. Ecologia das restingas do Sudeste do Brasil. I. Arq. Mus. Nac., RJ. 50: 185-236.

PERRIN, P. 1984. Evolução da costa fluminense entre as pontas de Itacoatiara e Negra: Preenchimento e restingas. In: Anais do Simpósio sobre Restingas Brasileiras, 1: 65-73. ill EDUFF. Niterói, RJ.

PRANCE, G.T. 1972. Chrysobalanaceae. Monografia. Flora Neotr., NY. 9: 1-410.

OLIVEIRA, A.S.; SENNA, L.M., PENA, E.M. \& ALVES, M.V.S. Euphorbiaceae Juss. - espécies ocorrentes nas restingas do Estado do Rio de Janeiro, Brasil. In: Resumos Congresso Nacional de Botânica, 39:613. Cuiabá.

RIZZINI, C.T. 1979. Tratado de Fitogeografia do Brasil. Hucitec, São Paulo. 2: 224-243.

SAMPAIO, A.J. de. 1946. Nomes vulgares de plantas do Distrito Federal e Estado do Rio de Janeiro. Bolm. Mus. Nac., RJ. 4: 1-149.

SILVA, J.G. da \& SOMNER, C.V. 1983. Plantas da restinga de Barra de Maricá, Rio de Janeiro. Rev. Bras. Farm., RJ. 64(2): 56-62.

— . \& - 1984. Restinga da Barra de Maricá, RJ. Levantamento preliminar da flora. In: Anais do Congresso Nacional de Botânica, 34(2): 351-365. Porto Alegre, RS.

— . \& . 1984a. A vegetação de restinga na Barra de Maricá, RJ. In: Anais do Simpósio sobre Restingas Brasileiras, 1: 217-225 ill. EDUFF. Niterói, RJ.

SMITH, L.B. 1955. The Bromeliaceae of Brasil. Smithsonian Miscellaneous Collections, Washington. 126(1): 1-275.

SEGUIO, K. \& TESSLER, M.G. 1984. Planície de cordões litorâneos quaternários do Brasil: Origem e nomenclatura. In: Anais do Simpósio sobre Restingas Brasileiras, 1: 15-25 ill. EDUFF. Niterói, RJ. 


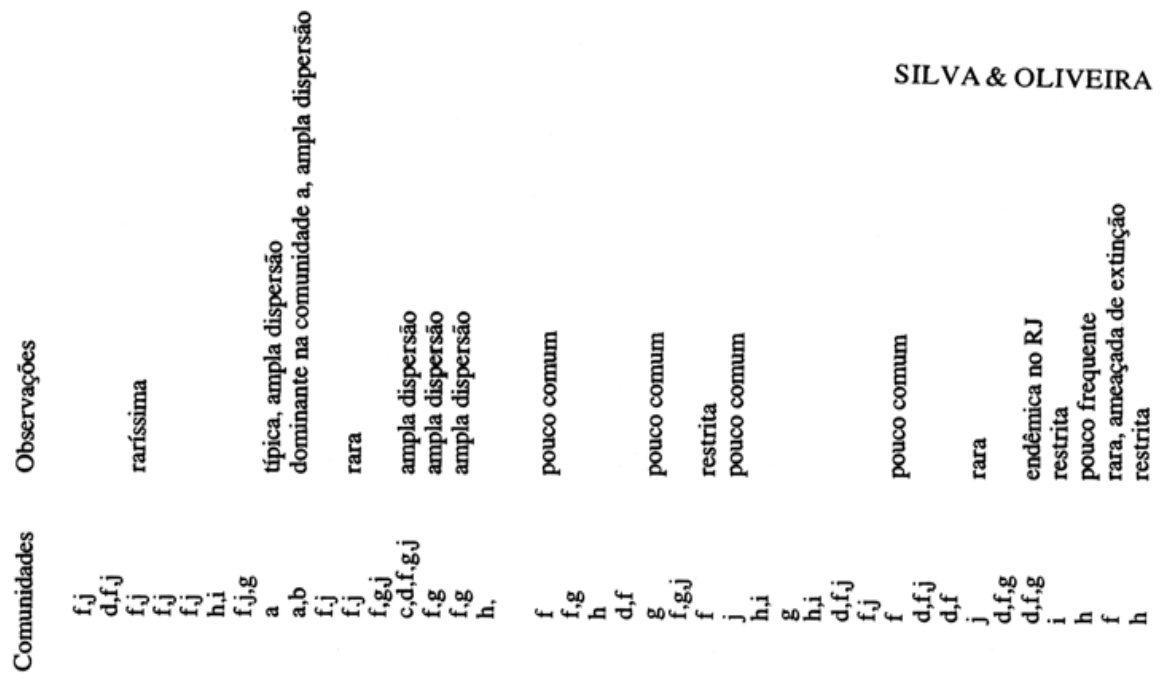

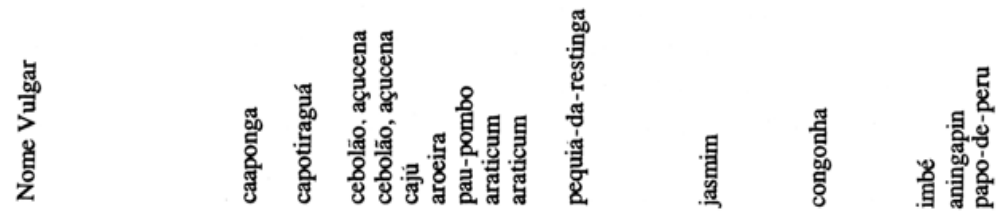
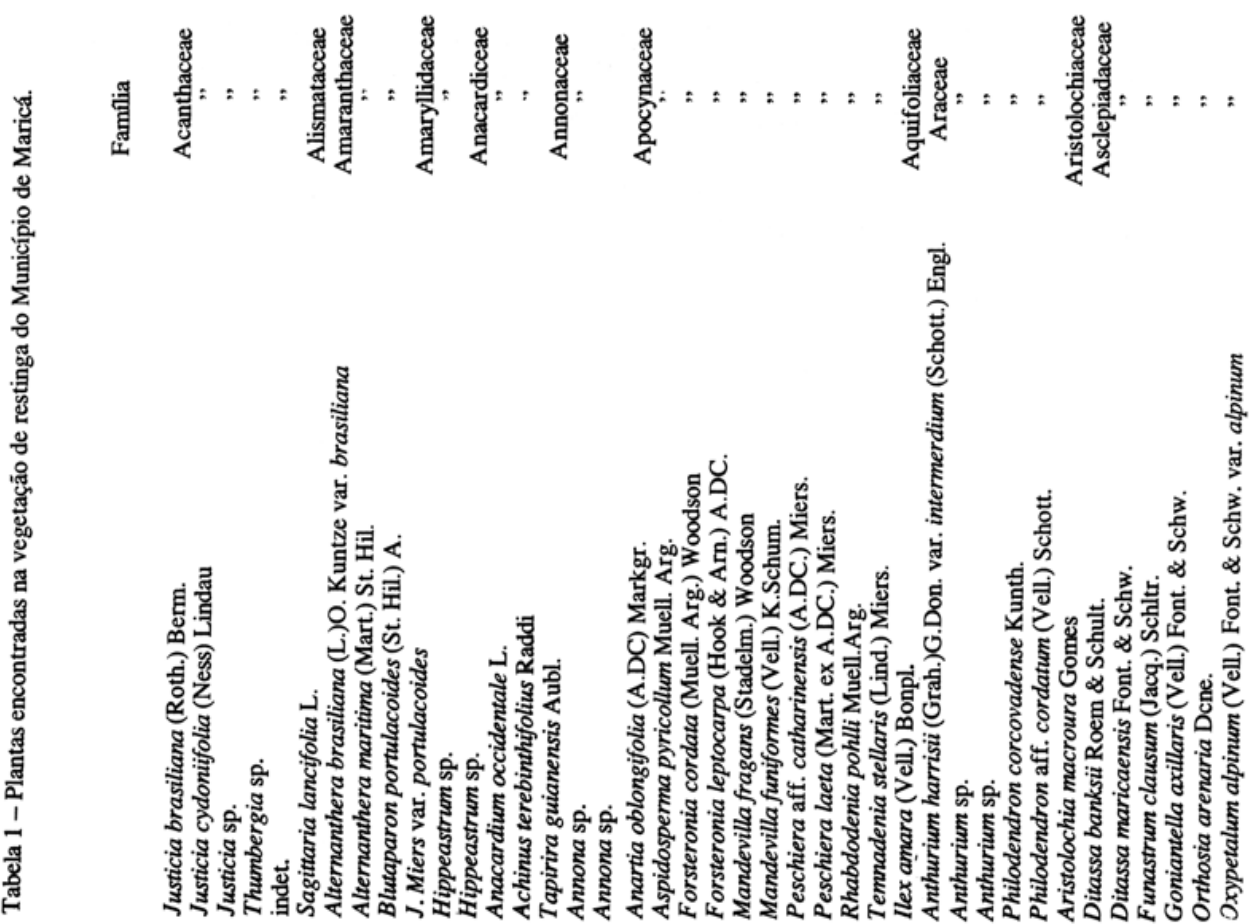


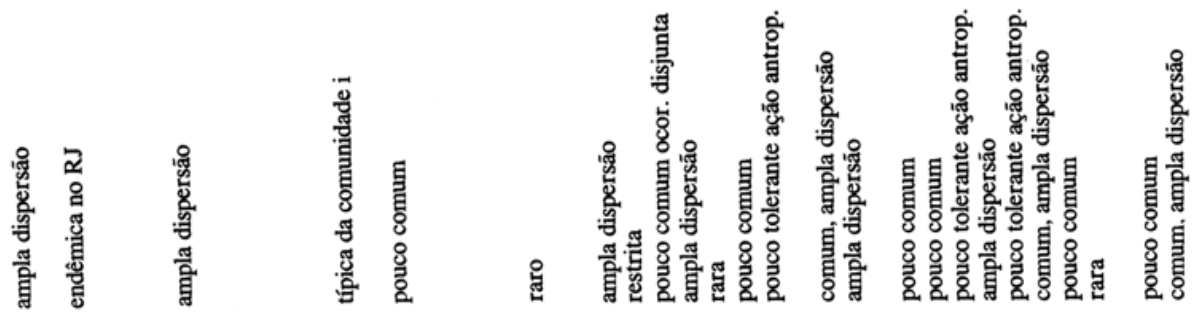

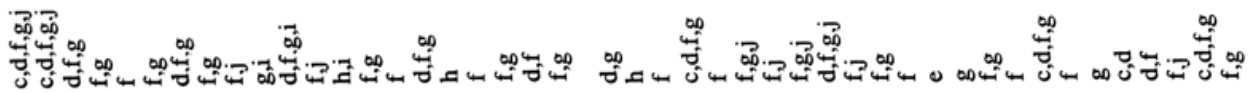

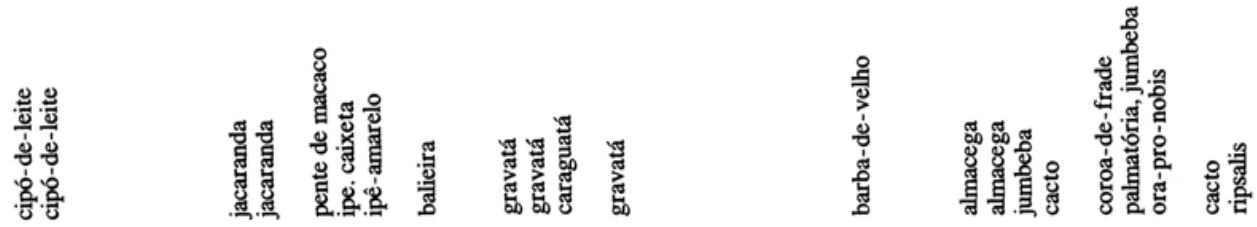

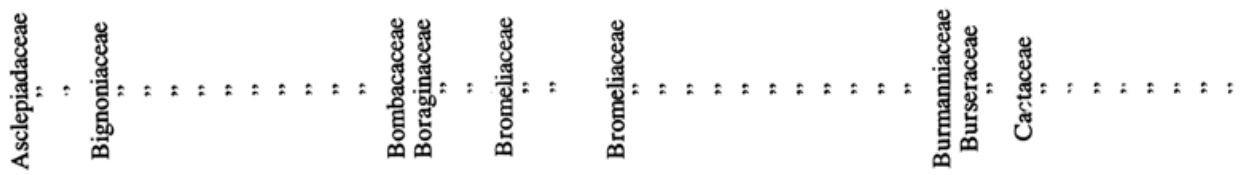

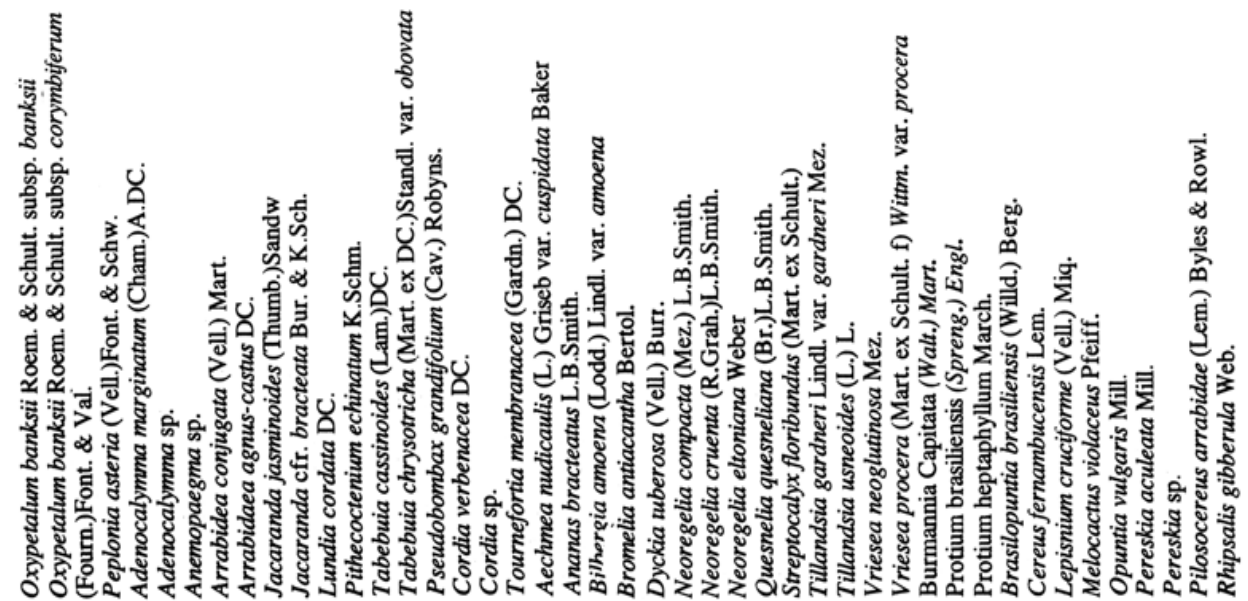



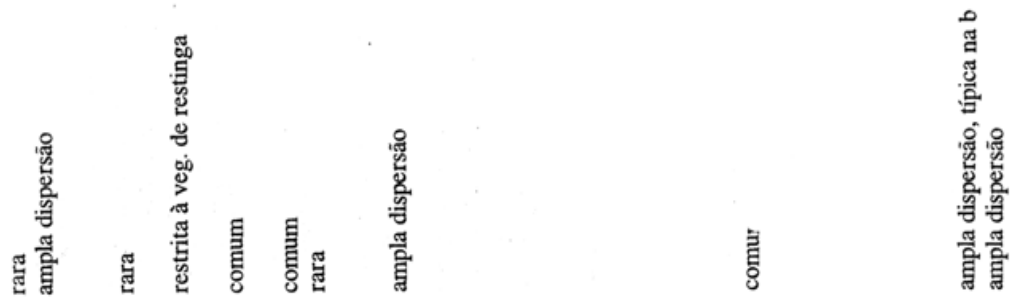

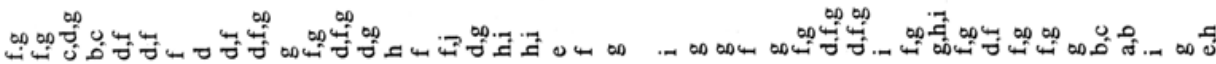

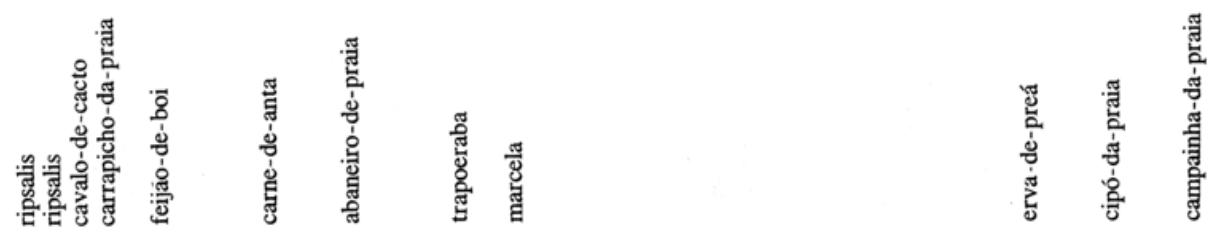

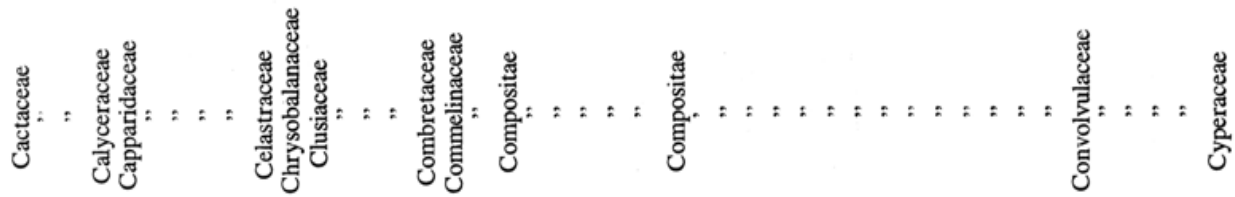

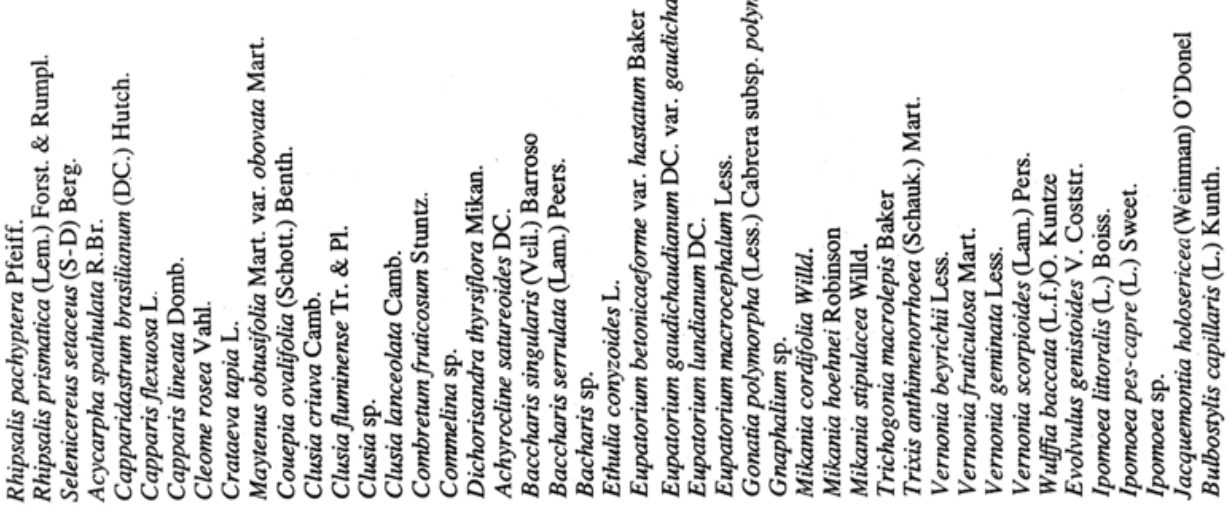




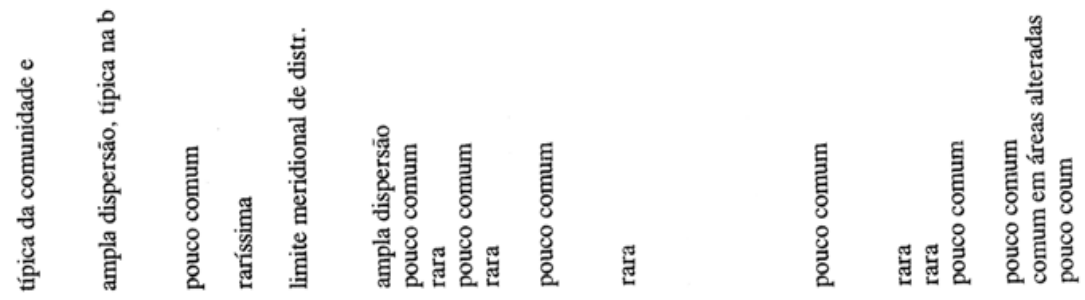

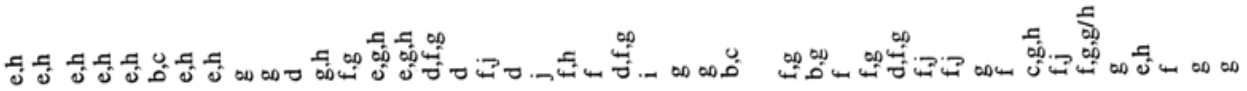

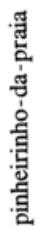

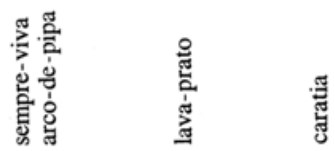

苋

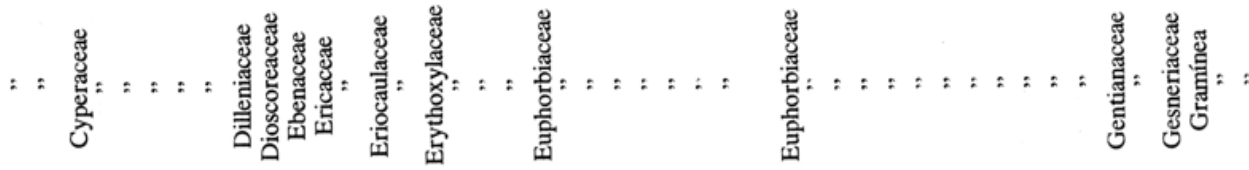

है

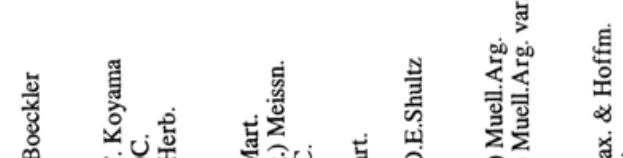

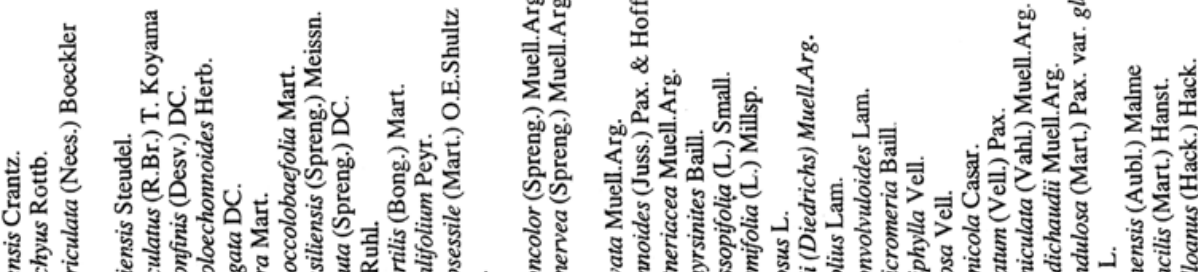

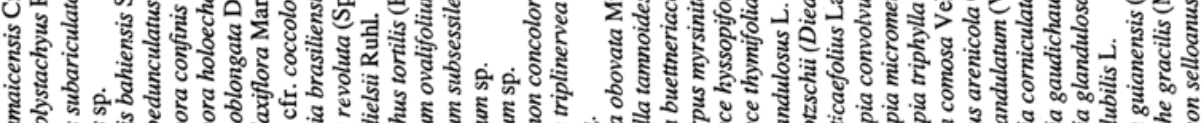

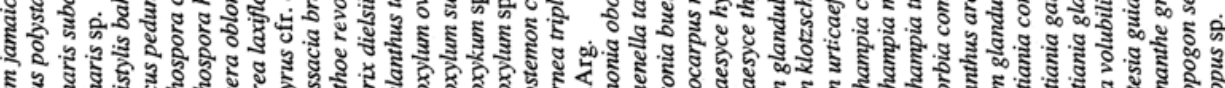

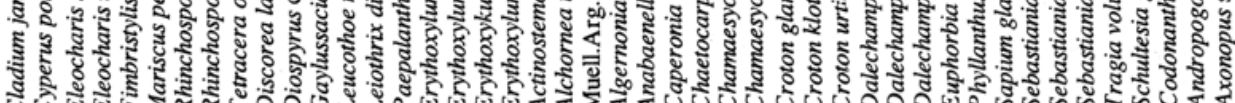


ह.

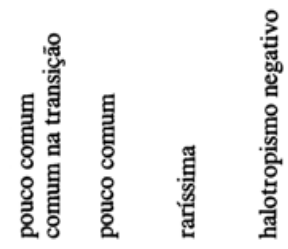

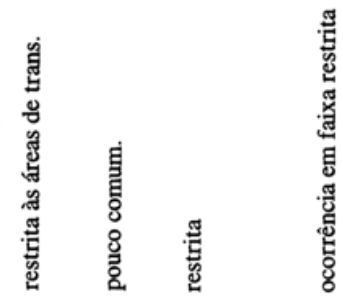

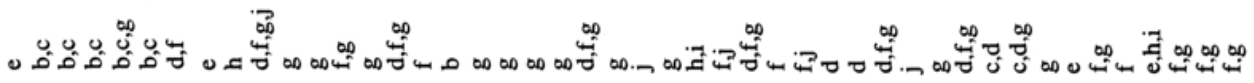

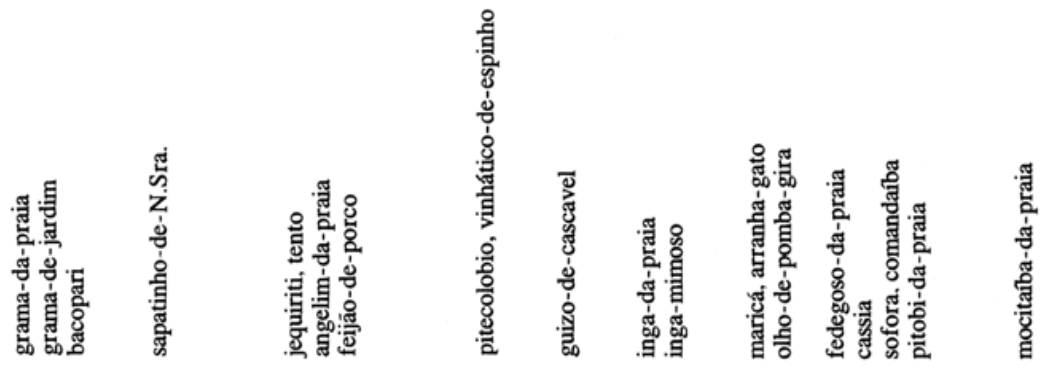

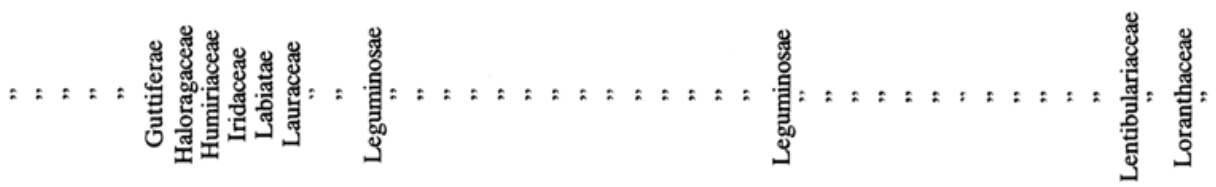

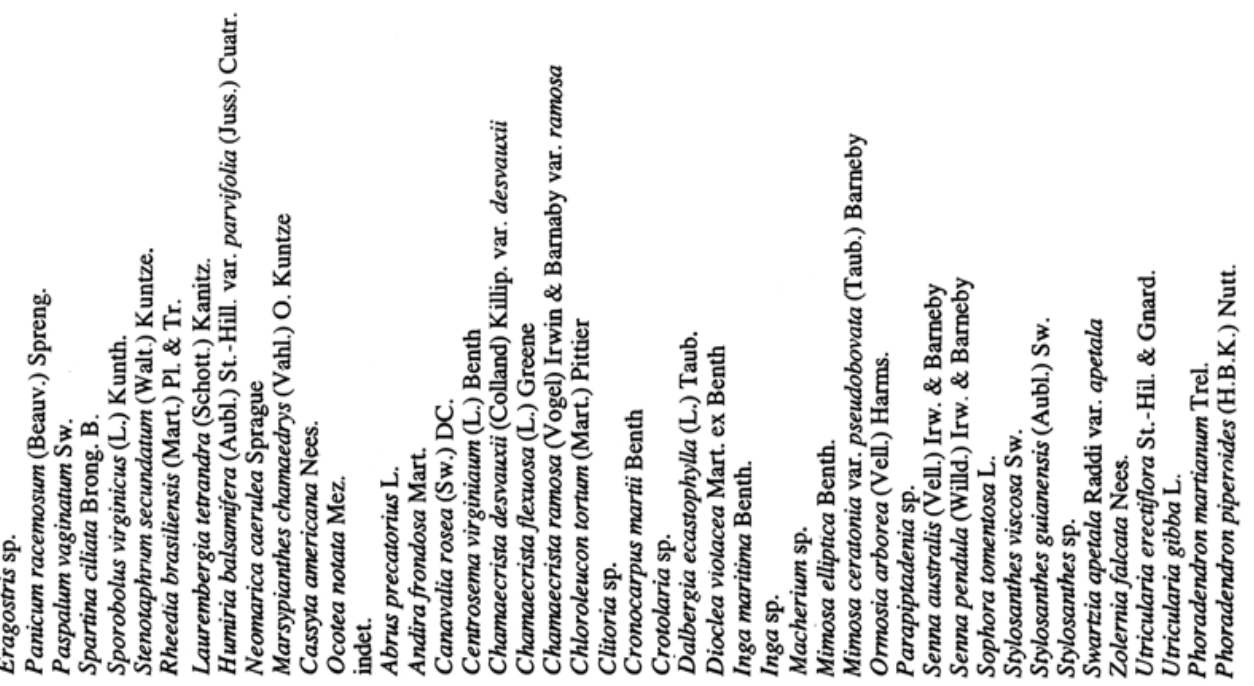




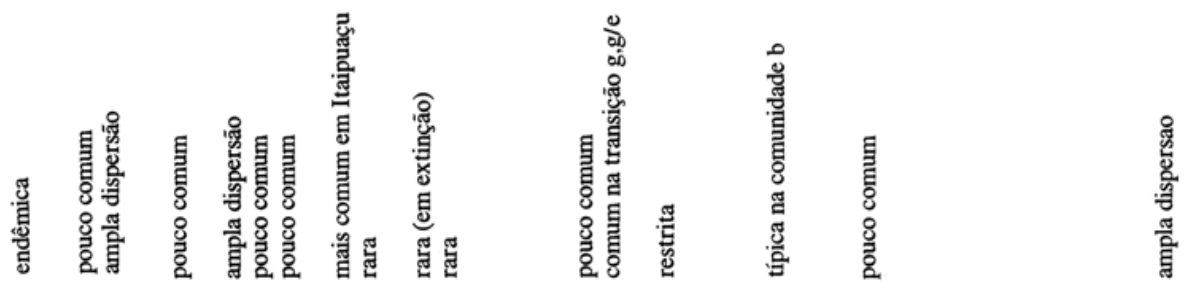
里电

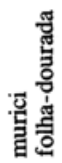

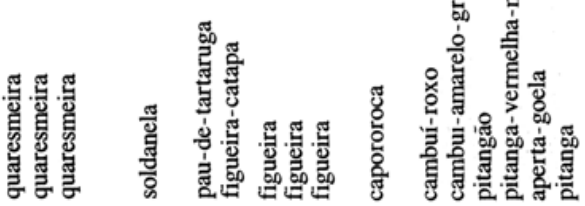

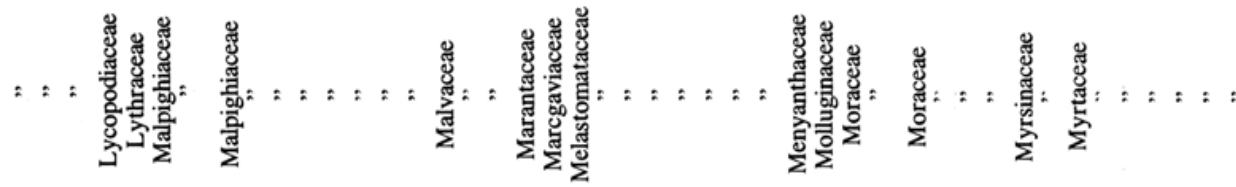

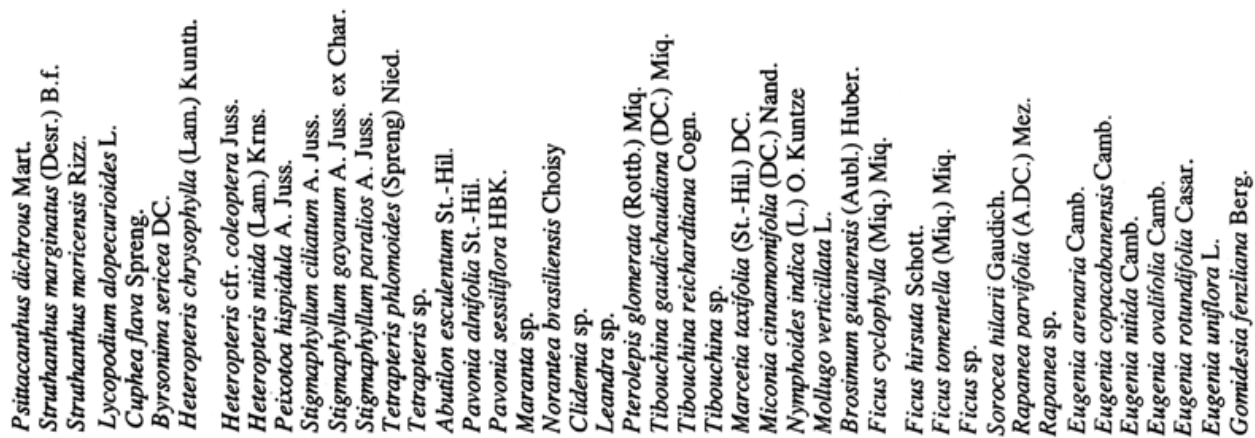




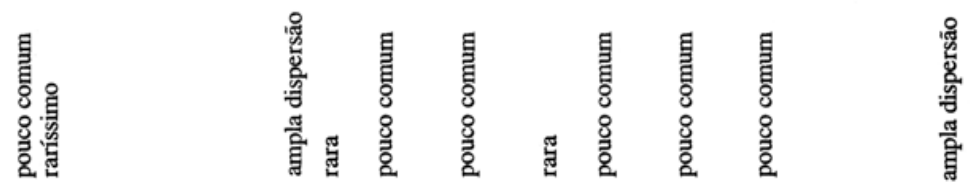

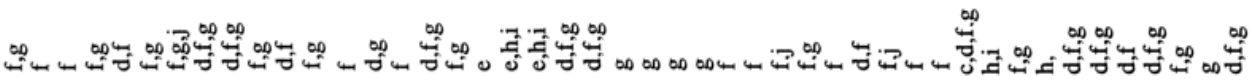
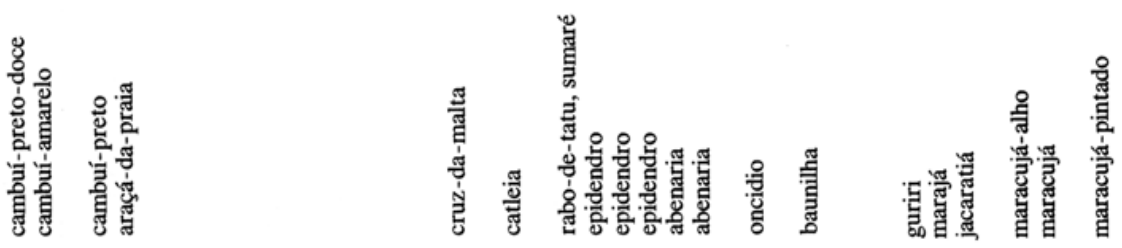

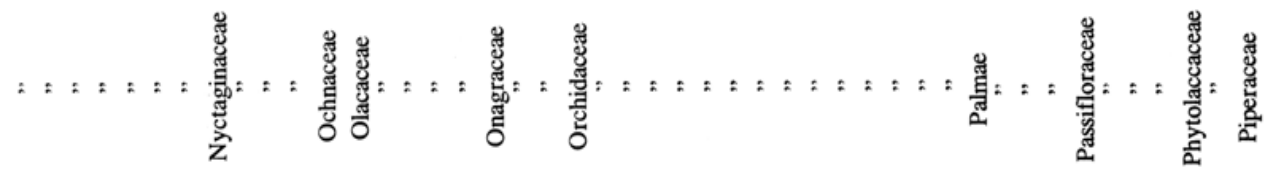

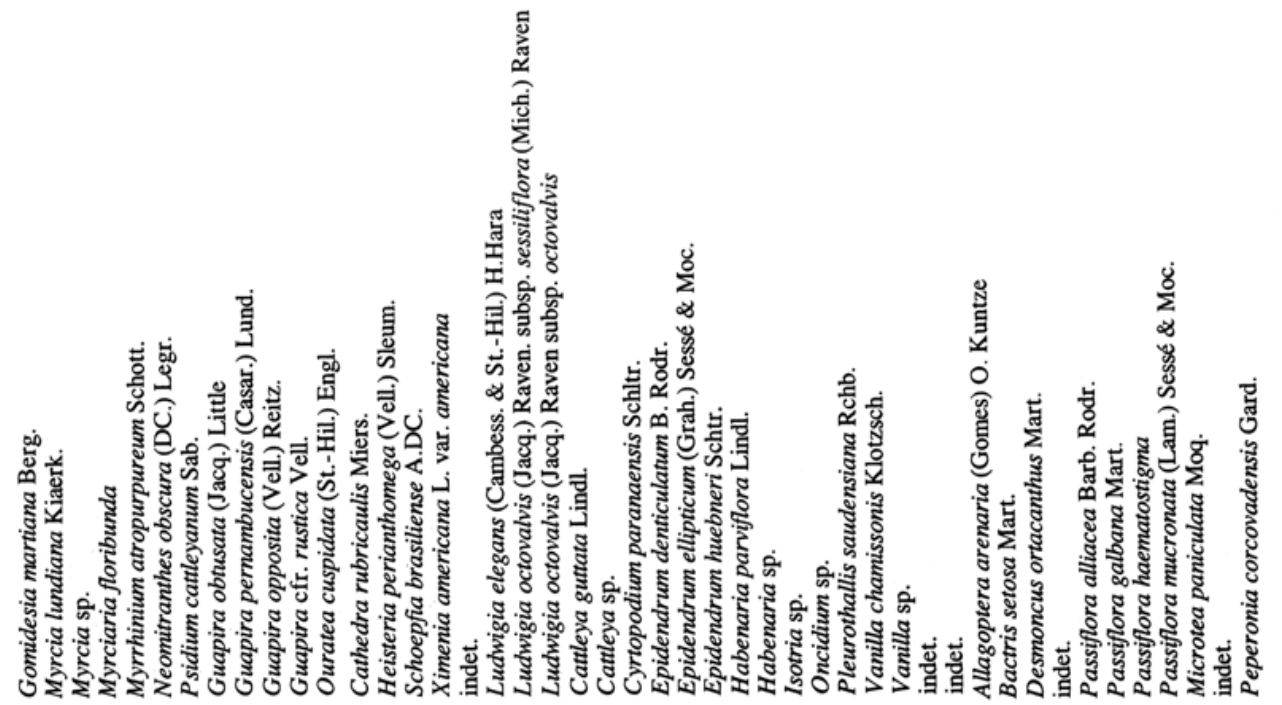



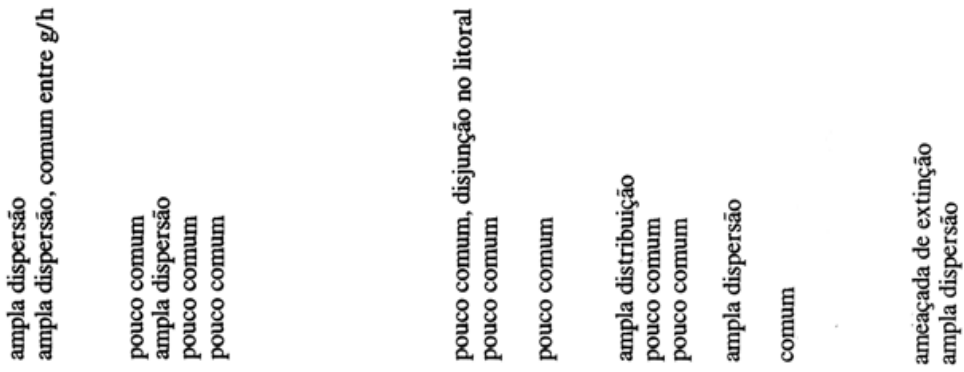

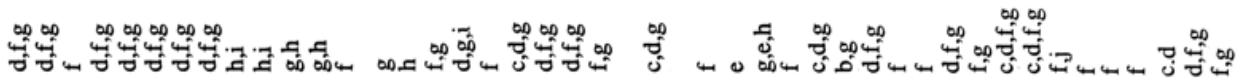

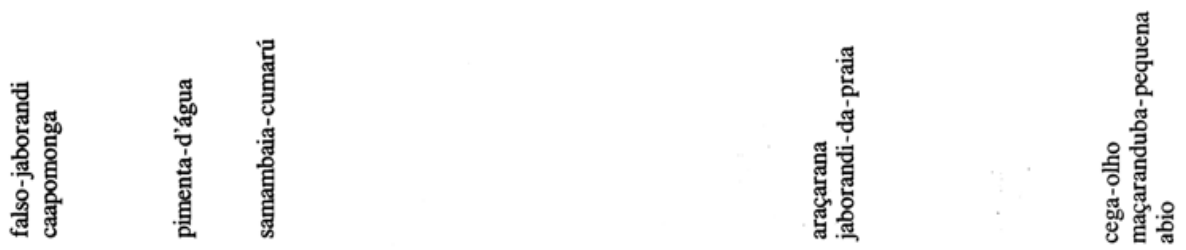

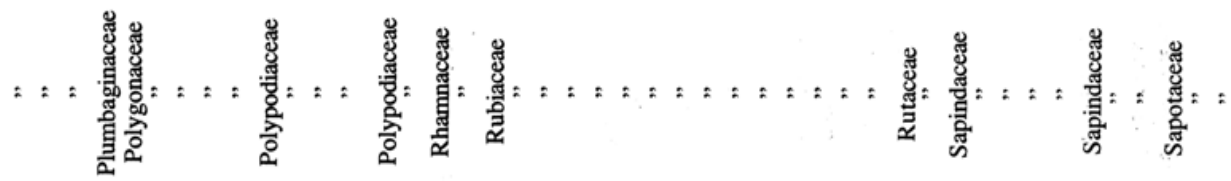

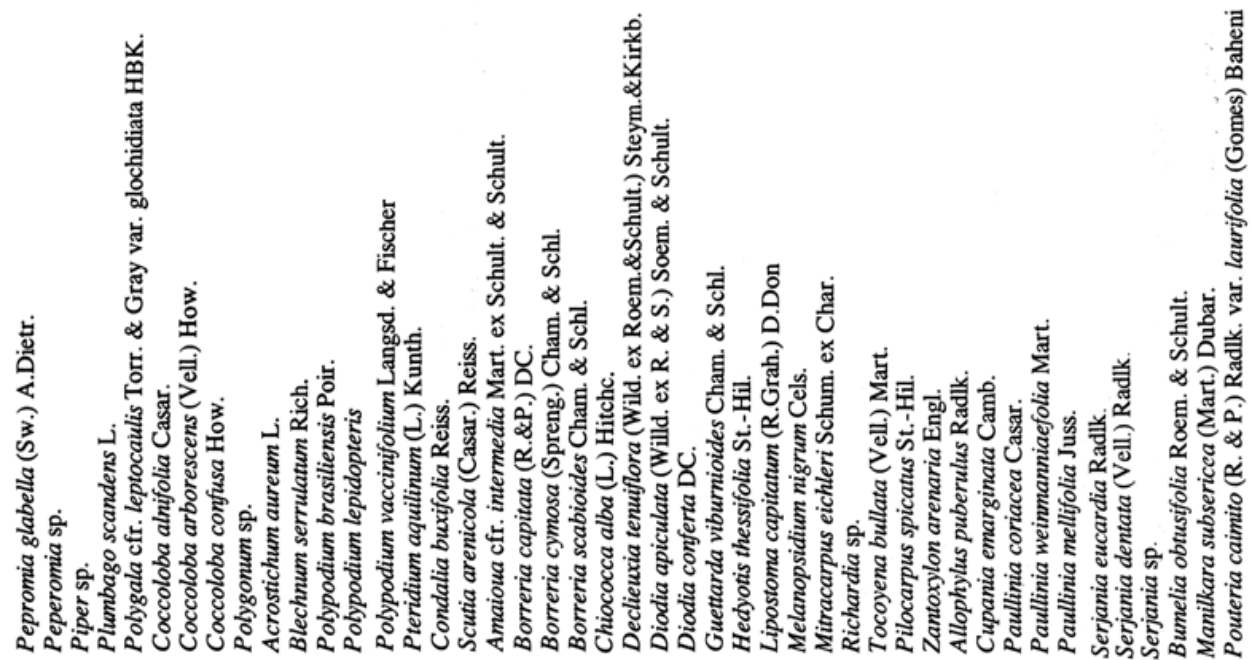




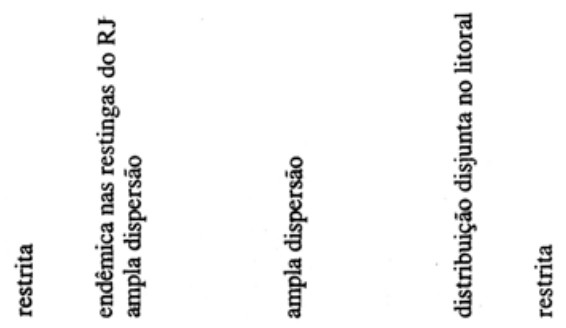

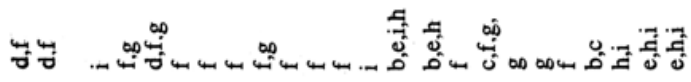

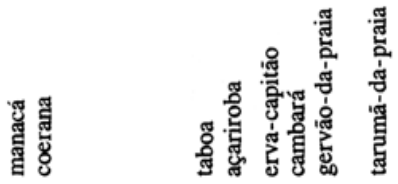

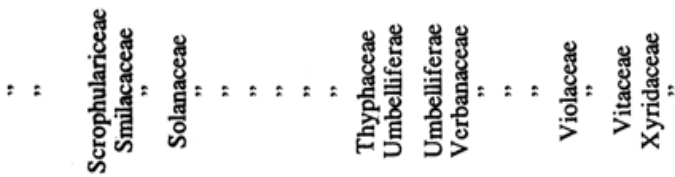

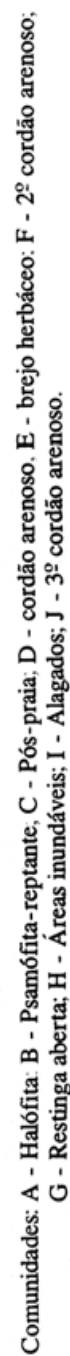




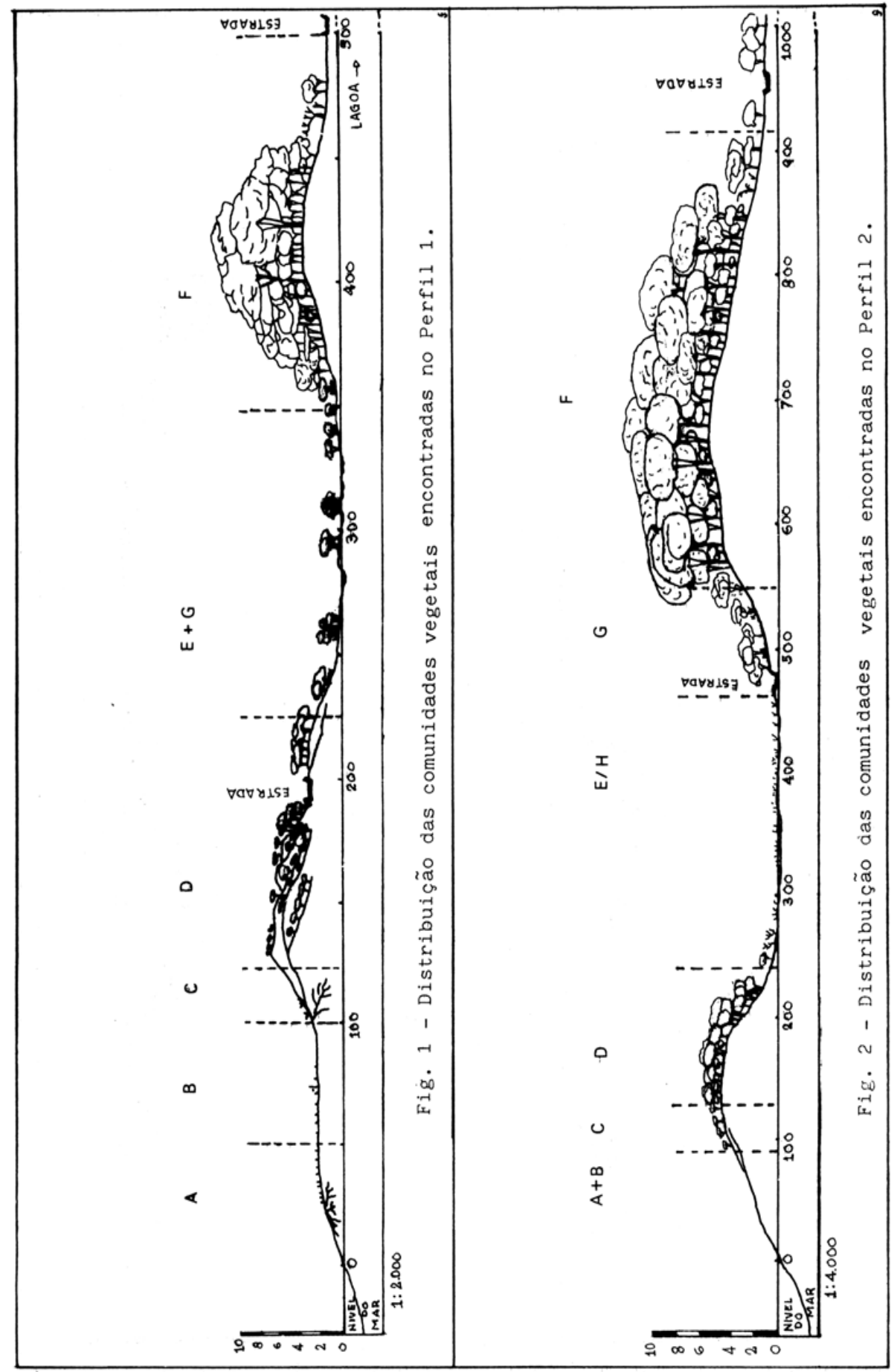




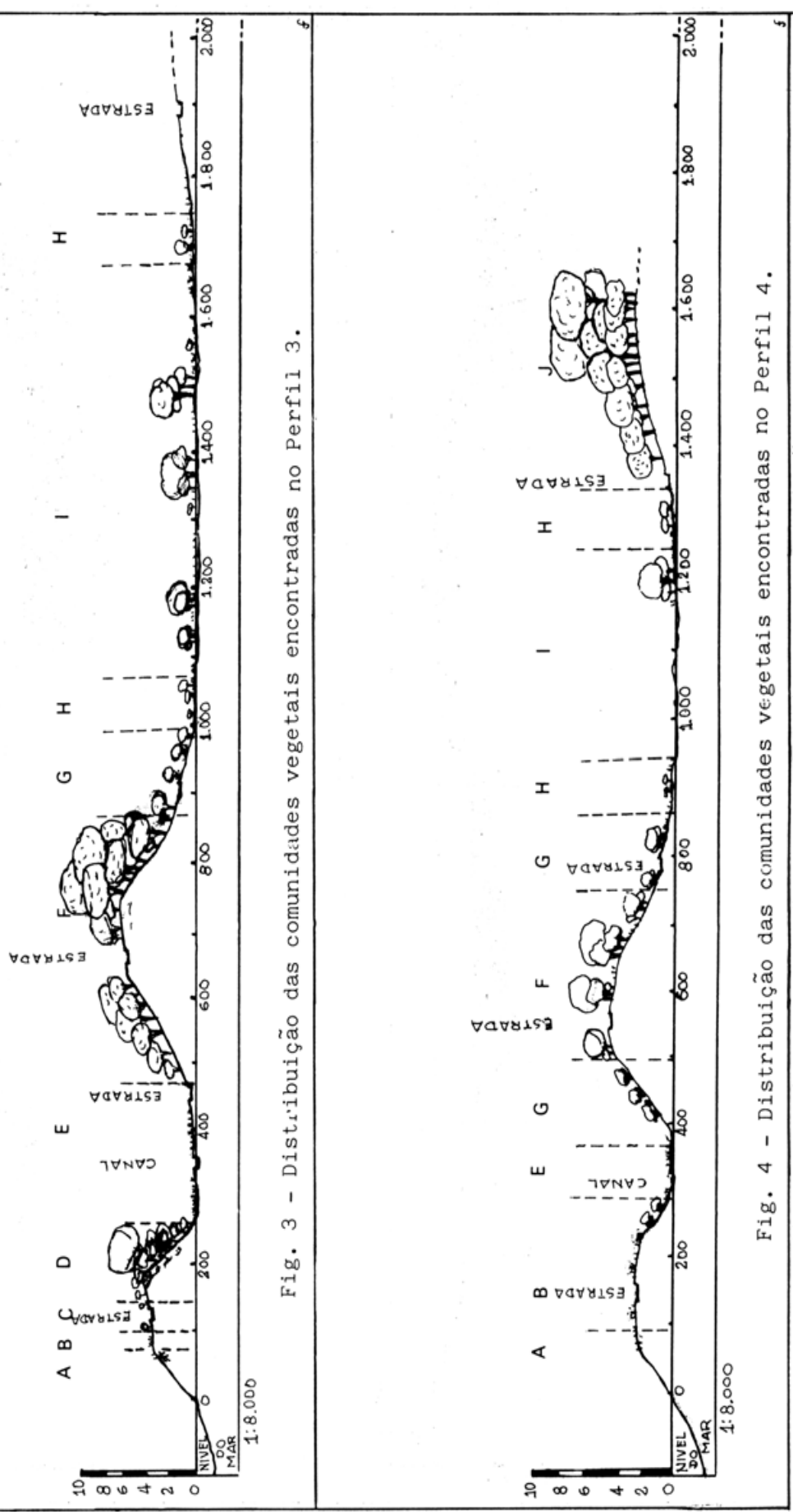

